\title{
A polymorphic microsatellite from the Squalius alburnoides complex (Osteichthyes, Cyprinidae) cloned by serendipity can be useful in genetic analysis of polyploids
}

\author{
Luis Boto ${ }^{1}$, Carina Cunha ${ }^{1,2}$ and Ignacio Doadrio ${ }^{1}$ \\ ${ }^{1}$ Departamento de Biodiversidad y Biología Evolutiva, Museo Nacional Ciencias Naturales, \\ CSIC, Madrid, Spain. \\ ${ }^{2}$ Instituto Universitário de Lisboa, Lisbon, Portugal.
}

\begin{abstract}
A new microsatellite locus (SAS1) for Squalius alburnoides was obtained through cloning by serendipity. The possible usefulness of this new species-specific microsatellite in genetic studies of this hybrid-species complex, was explored. The polymorphism exhibited by SAS1 microsatellite is an important addition to the set of microsatellites previously used in genetic studies in S. alburnoides complex, that mostly relied in markers described for other species. Moreover, the SAS1 microsatellite could be used to identify the parental genomes of the complex, complementing other methods recently described for the same purpose..
\end{abstract}

Key words: microsatellites, hybridogenesis, Squalius alburnoides.

Received: July 13, 2010; Accepted: March 23, 2011.

The taxon Squalius alburnoides is a small endemic cyprinid inhabiting the rivers of the Iberian Peninsula and is among the most complex polyploid systems known in vertebrates.

Based on molecular markers information, $S$. alburnoides is recognized as a hybrid taxon resulting from an ancient and unidirectional hybridization between $S$. pyrenaicus females (P genome) and males (A genome) of an extinct species sister to Anaecypris hispanica (reviewed in Alves et al. 2001, Robalo et al. 2006). For this reason, all the S.alburnoides fishes carry S.pyrenaicus mitochondrial DNA.

Actually, the $S$. alburnoides complex combines the diploid $(2 n=50)$ and polyploid $(3 n=75$ and $4 n=100)$ biotypes of both sexes and different nuclear genomes, that, by intercrossing, combine sexual and asexual reproductive modes.

The asexual modes range from clonal inheritance to hybridogenesis or meiotic hybridogenesis (in which one genome is excluded from gamete formation), whereby sympatric bisexual Squalius species act as sperm donors and contribute with new genetic material, i.e.., $S$. pyrenaicus, mainly in the southern basins of the Iberian Peninsula (P genome), and S. carolitertii in the northern (C genome)) (reviewed in Alves et al., 2001; Pala et al., 2009).

Send correspondence to Luis Boto. Departamento de Biodiversidad y Biología Evolutiva, Museo Nacional de Ciencias Naturales, CSIC, C/ José Gutiérrez Abascal 2, 28006 Madrid, Spain. E-mail: mcnb119@mncn.csic.es.
The predominant $S$. alburnoides specimens in nature are triploids with the sex ratio biased towards females, with the CAA biotype across the distribution range of $S$. carolitertii, and the PAA biotype across the $S$. pyrenaicus range.

As in other asexual complexes (Ambystoma: Bogart, 1989; Rana: Hotz et al.,1992; Phoxinus: Goddard and Schultz, 1993), the S. alburnoides complex have regenerated and maintained the extinct parental species genotype (AA, all males) through the fertilization of A ovocytes from PAA females by reduced A sperm produced by AA males of hybrid origin (Alves et al., 2002). This AA genotype is apparently absent from the northern populations

Although in recent times, single nucleotide polymorphisms (SNPs) have disputed with microsatellites the role of a prominent tool in genetic studies (Coates et al. 2009), mainly through single nucleotide changes being universally comparable, polymorphic DNA microsatellites remain as a very useful (and less expensive) class of genetic markers in population genetics. Moreover, in general, microsatellites are more neutral than SNPs, since the latter frequently give evidence of selection

Microsatellites, by addressing topics, such as genetic identification, population structure, parentage, kinship and population variability assessment (Jarne and Lagoda, 1996; Goldstein et al., 1999; Ellegren, 2004; Hamilton and Tyler, 2008), are traditionally considered as the markers of choice for genotyping, due to their abundance, polymorphism in repeat numbers and reliability (Jones et al. 1997). 
Microsatellites display a very high content of genetic information, as they are codominant, with multiple alleles, and showing high expected heterozygosity values.

In addition to the abundance of microsatellites in vertebrate genomes (Weber, 1990; Jarne and Lagoda, 1996; Goldstein and Schlötterer, 1999), it is notable that, in fish, microsatellite-loci are longer, have a larger range in allele size, are more degenerated (i.e., contain more base substitutions or deletions), and are very abundant, when compared to mammals (e.g., Brooker et al.,1994; Colbourne et al., 1996; O'Reilly et al., 1996; Neff and Gross, 2001). The possibility of using microsatellites described for another closely related species (transferability of microsatellite loci) is a consequence of homology of flanking regions in simple sequence repeats (Turner et al., 2004). Studies in freshwater fish have already demonstrated the high rate of transferability of microsatellite loci among taxonomically related species (e.g. Huang et al., 2003; Salgueiro et al., 2003; Turner et al., 2004; Holmen et al., 2005).

Efforts to determine the copy number of microsatellite alleles in polyploid species have, in many cases, been unsuccessful (Falque et al., 1998) and in some cases no attempts have even been made to assign precise allelic configurations (Becher et al., 2000; Bockelmann et al., 2003). There are many applications where considerably more information would be gained from a proper quantification of the alleles in the loci analysed, such as population genetics and paternity analysis.

In the $S$. alburnoides complex, microsatellite loci are often used for estimating population genetic diversity and evolutionary potential (Pala and Coelho, 2005; CrespoLópez et al., 2007; Cunha et al., 2008, 2011), verifying inheritance patterns (Alves et al., 2004), and analyzing reproduction modes (Crespo-López et al., 2006). They are also efficient markers, not only for detecting diagnostic alleles for each parental genome, but also for characterizing genetic variability in polyploids (e.g. Christiansen, 2005; Lampert et al., 2006; Ramsden et al., 2006; Cunha et al., 2008).

In the present report, the cloning by serendipity of a polymorphic microsatellite from a diploid S. alburnoides specimen from Estena River (Guadiana basin, Spain) is described, with a discussion of its possible application in studies of the characterization of genetic variability and parental assignment in this species complex.

The microsatellite was discovered during a series of trials for cloning short opsin fragments from S. alburnoides (Boto unpublished). Briefly, amplification of a short fragment of the exon five in the putative SWS1 opsin gene was attempted, by using a degenerate universal vertebrate forward primer OPF 5GCGAATTCGCNTCNACNCARA ARGCNGA 3 (Carleton et al., 2000) and a primer designed against a short Cyprinus carpio SWS1 sequence OPC1R 5CCTTGTTTGTATCCTCAGCA 3. DNA was extracted from fins preserved in ethanol, using standard methods (Sambrook et al., 1989).

Gradient Polymerase Chain Reaction (Eppendorf MasterCycler Gradient) ( $3 \mathrm{~min}$. at $94{ }^{\circ} \mathrm{C}, 35$ cycles of $1 \mathrm{~min}$. at $94{ }^{\circ} \mathrm{C}, 1 \mathrm{~min}$. at $52 \pm 10^{\circ} \mathrm{C}, 1 \mathrm{~min}$. at $72{ }^{\circ} \mathrm{C}$, and a final step of $3 \mathrm{~min}$. at $72^{\circ} \mathrm{C}$ ), yielded bands compatible with the expected opsin fragment at temperatures of 42.1 to $44.2{ }^{\circ} \mathrm{C}$.

An aliquot of $15 \mu \mathrm{L}$ of a pooled mix of amplified fragments was precipitated with isopropanol and ligated to a PGEM-T vector. TOPO-competent bacteria were transformed with the ligation mix and plated onto LB/agar/ampicilin.

From the 18 transformants bearing an insert of compatible length with the expected fragment sequenced (ABI 3730), 15 bore an AG microsatellite sequence.

Three of these sequences presented 12 repeats of the AG motif, five 13, two 24 , two 25 and three 26. Seeing that DNA polymerase is capable of copying the same allele with different repeat numbers (Hauge and Litt, 1993; Clarke et al., 2001; Ellegren, 2004), the cloning of two different alleles (12-13 repeats and 24-26 repeats) from this microsatellite can be inferred.

A representative sequence, denominated SASI, is deposited in GenBank under accession number FJ652104.

In order to explore both the polymorphic character of this microsatellite, and its usefulness in further studies of the $S$. alburnoides complex, DNA from individuals of different geographic origin, genome composition and ploidy level, as well as several S.pyrenaicus and S. carolitertii samples, was amplified (Table 1), using OPF and OPC1R primers (the latter marked with FAM), at a hybridization temperature of $43.5^{\circ} \mathrm{C}$. Fragments were analyzed with an ABI 3730 using GeneMapper v3.7.

After prior identification of the biotype, according to procedures by Cunha et al. $(2008,2009)$, ploidy levels were determined through flow cytometry (FCM) of blood cells, as previously described (Collares-Pereira and Moreira de Costa, 1999).

As shown (Table 1), this microsatellite facilitates the discrimination between alleles coming from the genome of the extinct ancestor close to Anaecypris hispanica (Robalo et al., 2006) - genome A (allele length below $100 \mathrm{bp}$ ), and those from the $\mathrm{P}$ or $\mathrm{C}$ genomes corresponding to the $S$. pyrenaicus and $S$. carolitertii sperm donors (allele lengths above $100 \mathrm{bp}$ ). As such, this microsatellite could be used to differentiate individuals with hybrid genomes from individuals with a single genome.

This microsatellite does not allow distinguishing the alleles coming from the sperm donors, with genomes $\mathrm{P}$ or $\mathrm{C}$, whose alleles overlap in length. However, this is a minor problem, since populations carrying $\mathrm{P}$ or $\mathrm{C}$ genomes are allopatric

Due to manifest polymorphism, the SAS1 microsatellite became an important addition to those previously 
used in genetic studies of the $S$. alburnoides hybrid complex [n7k4, n7j4, e2f8 and e1g6 (Mesquita et al., 2003; Pala and Coelho, 2005) lco1, lco3, lco4 and lco5 (Turner et al. 2004) loci], since only two (e2f8 and elg6) were really S.alburnoides-complex specific.

Furthermore, the identification of heterozygotes with the SAS1 microsatellite could be of use for detecting the genome copy number of intergeneric hybrids, despite the

Table 1 - SAS1 genotypes from various S.alburnoides, S.pyrenaicus and $S$. carolitertii individuals, coming from different basins and presenting a diverse ploidy and genomic composition.

\begin{tabular}{|c|c|c|c|}
\hline Species & Basin & Genomic composition & Genotype \\
\hline S. pyrenaicus & Guadiana & $\mathrm{PP}$ & $110 / 116$ \\
\hline S. Pyrenaicus & Guadiana & PP & $108 / 114$ \\
\hline S. pyrenaicus & Guadiana & PP & $100 / 112$ \\
\hline S. pyrenaicus & Guadiana & $\mathrm{PP}$ & $104 / 128$ \\
\hline S. pyrenaicus & Guadiana & $\mathrm{PP}$ & $104 / 116$ \\
\hline S. pyrenaicus & Guadiana & $\mathrm{PP}$ & $100 / 100$ \\
\hline S. pyrenaicus & Guadiana & PP & $110 / 110$ \\
\hline S. pyrenaicus & Guadiana & PP & $116 / 124$ \\
\hline S. pyrenaicus & Guadiana & PP & $102 / 102$ \\
\hline S. pyrenaicus & Guadiana & PP & $116 / 132$ \\
\hline S. pyrenaicus & Guadiana & $\mathrm{PP}$ & $116 / 116$ \\
\hline S. carolitertii & Douro & $\mathrm{CC}$ & $108 / 110$ \\
\hline S. carolitertii & Douro & $\mathrm{CC}$ & $114 / 114$ \\
\hline S. carolitertii & Douro & $\mathrm{CC}$ & $108 / 108$ \\
\hline S. carolitertii & Douro & $\mathrm{CC}$ & $108 / 108$ \\
\hline S. carolitertii & Douro & $\mathrm{CC}$ & $104 / 104$ \\
\hline S. carolitertii & Douro & $\mathrm{CC}$ & $104 / 112$ \\
\hline S. carolitertii & Douro & $\mathrm{CC}$ & $108 / 114$ \\
\hline S.alburnoides & Guadiana & AA & $92 / 94$ \\
\hline S. alburnoides & Guadiana & AA & $92 / 92$ \\
\hline S. alburnoides & Guadiana & AA & $90 / 90$ \\
\hline S. alburnoides & Guadiana & AA & $92 / 92$ \\
\hline S. alburnoides & Guadiana & AA & $90 / 92$ \\
\hline S. alburnoides & Tagus & $\mathrm{AP}$ & $92 / 130$ \\
\hline S. alburnoides & Tagus & $\mathrm{AP}$ & $86 / 136$ \\
\hline S. alburnoides & Douro & $\mathrm{ACC}$ & $86 / 114 / 114$ \\
\hline S. alburnoides & Douro & $\mathrm{ACC}$ & $86 / 114 / 114$ \\
\hline S. alburnoides & Douro & $\mathrm{AAC}$ & $86 / 88 / 108$ \\
\hline S. alburnoides & Douro & $\mathrm{AAC}$ & $88 / 88 / 118$ \\
\hline S. alburnoides & Douro & $\mathrm{AAC}$ & $88 / 88 / 108$ \\
\hline S. alburnoides & Douro & $\mathrm{AAC}$ & $88 / 88 / 108$ \\
\hline S. alburnoides & Tagus & AAP & $86 / 86 / 110$ \\
\hline S. alburnoides & Tagus & $\mathrm{AAP}$ & $86 / 86 / 134$ \\
\hline S. alburnoides & Guadiana & AAP & $92 / 92 / 112$ \\
\hline S. alburnoides & Guadiana & AAP & $92 / 94 / 112$ \\
\hline S. alburnoides & Douro & $\mathrm{AACC}$ & $86 / 86 / 112 / 112$ \\
\hline S. alburnoides & Douro & $\mathrm{AACC}$ & $86 / 86 / 118 / 118$ \\
\hline S. alburnoides & Douro & $\mathrm{AACC}$ & $86 / 86 / 114 / 114$ \\
\hline S. alburnoides & Douro & $\mathrm{AACC}$ & $86 / 86 / 114 / 114$ \\
\hline
\end{tabular}

existence of new methods for quickly defining the genomic composition of Squalius alburnoides, based on determining the relative genome dosage by the semiquantitative polymerase chain reaction (PCR) method (Sousa-Santos et al., 2005; Inacio et al., 2010).

As shown above, the microsatellite loci previously used in genetic studies of S. alburnoides (Pala and Coelho, 2005; Crespo-López et. al., 2006, 2007; Cunha et al., 2008) were mostly heterologous ones. This frequently leads to the appearance of null alleles (alleles which are not amplified) and a loss in polymorphism information in the species in which the marker was being tested. The increase in the number of microsatellite loci in genetic studies has been shown to be a beneficial strategy, through minimizing problems derived from characteristics of the microsatellites themselves (high mutation rate, presence of null alleles, size homoplasy, etc.). Hence, the addition of a new one constitutes a powerful tool for increasing knowledge

\section{Acknowledgments}

This work is funded by grants from Spanish DGI (CGL 2010-15231) and Spanish MMA. (115/2003). The authors are indebted to an anonymous reviewer for suggestions that substantially improved the manuscript

\section{References}

Alves MJ, Coelho MM and Collares-Pereira MJ (2001) Evolution in action through hybridization and polyploidy in an Iberian freshwater fish: A genetic review. Genetica 111:375-385.

Alves MJ, Collares-Pereira MJ, Dowling TE and Coelho MM (2002) The genetics of maintenance of an all-male lineage in the Squalius alburnoides complex. J Fish Biol 60:649-662.

Alves MJ, Gromicho M, Collares-Pereira MJ, Crespo-López, E and Coelho MM (2004) Simultaneous production of triploid and haploid eggs by triploid Squalius alburnoides (Teleostei, Cyprinidae). J Exp Zool 301:552-558.

Becher SA, Steinmetz K, Weising K, Boury S, Peltier D, Renou JP, Kahl G and Wolff K (2000) Microsatellites for cultivar identification in Pelargonium. Theor Appl Genet 101:643651.

Bockelmann AC, Reusch TBH, Bijlsma R and Bakker JP (2003) Habitat differentiation $v s$. isolation-by-distance: The genetic population structure of Elymus athericus in European salt marshes. Mol Ecol 12:505-515.

Bogart JP (1989) A mechanism for interspecific gene exchange via all-female salamander hybrids. In: Dawley RM and Bogart JP (eds) Evolution and Ecology of Unisexual Vertebrates. New York State Museum, New York, pp 170-179.

Brooker AL, Cook D, Bentzen P, Wright JM and Doyle RW (1994) Organization of microsatellites differs between mammals and coldwater teleost fishes. Can J Fish Aquat Sci 51:1959-1966.

Carleton KL, Harosi FI and Kocher TD (2000) Visual pigments of African cichlid fishes: Evidence for ultraviolet vision from microspectrophotometry and DNA sequences. Vision Res 40:879-890. 
Christiansen DG (2005) A microsatellite-based method for genotyping diploid and triploid water frogs of the Rana esculenta hybrid complex. Mol Ecol Notes 5:190-193.

Clarke LA, Rebelo CS, Gonçalves J, Boavida MG and Jordan P (2001) PCR amplification introduces errors into mononucleotide and dinucleotide repeat sequences. J Clin Pathol Mol Pathol 54:351-353.

Coates, BS, Sumerford DV, Miller NJ, Kim KS, Sappington TW, Siegfried BD and Lewis LC (2009) Comparative performance of single nucleotide polymorphism and microsatellite markers for population genetic analysis. J Hered 100:556564.

Colbourne JK, Neff BD, Wright JM and Gross MR (1996) DNA fingerprinting of bluegill sunfish (Lepomis macrochirus) using (AC)n microsatellites and its potential for assessment of mating success. Can J Fish Aquat Sci 53:342-349.

Collares-Pereira MJ and Moreira da Costa L (1999) Intraspecific and interspecific genome size variation in Iberian Cyprinidae and the problem of diploidy and poplyploidy, with review of genome sizes within the family. Folia Zool Brno 48:61-76.

Crespo-López ME, Duarte T, Dowling T and Coelho MM. (2006) Modes of reproduction of the hybridogenetic fish Squalius alburnoides in the Tejo and Guadiana rivers: An approach with microsatellites. Zoology 109, 277-286.

Crespo-López ME, Pala I, Duarte TL, Dowling TE and Coelho MM (2007) Genetic structure of the diploid-polyploid fish Squalius alburnoides in southern Iberian basins Tejo and Guadiana, based on microsatellites. J Fish Biol 71:423-436.

Cunha C, Doadrio I and Coelho MM (2008) Speciation towards tetraploidization after intermediate processes of non-sexual reproduction. Phil Trans R Soc Lond B Biol Sci 363:29212929.

Cunha C, Bastir M, Coelho MM and Doadrio I (2009) Body shape evolution among ploidy levels of the $S$. alburnoides hybrid complex (Teleostei, Cyprinidae). J Evol Biol 22:718-728.

Cunha C, Doadrio I, Abrantes J and Coelho MM (2011) The evolutionary history of the allopolyploid Squalius alburnoides (Cyprinidae) complex in the northern Iberian Peninsula. Heredity 106:100-112.

Ellegren H (2004) Microsatellites: Simple sequences with complex evolution. Nat Rev Genet 5:435-445.

Falque M, Keurentjes J, Bakx-Schotman JMT and Van Dijk PJ (1998) Development and characterization of microsatellite markers in the sexual-apomictic complex Taraxacum officinale (dandelion). Theor Appl Genet 97:283-292.

Goddard KA and Schultz RJ (1993) Aclonal reproduction by polyploid members of the clonal hybrid species Phoxinus eos-neogaeus (Cyprinidae). Copeia 1993:650-660.

Goldstein DB and Schlötterer C (1999) Microsatellites: Evolution and Applications. Oxford University Press, New York, $352 \mathrm{pp}$.

Goldstein DB, Roemer GW, Smith DA, Reich DE, Bergman A and Wayne RK (1999) The use of microsatellite variation to infer population structure and demographic history in a natural model system. Genetics 151:797-801.

Hamilton PB and Tyler CR (2008) Identification of microsatellite loci for parentage analysis in roach Rutilus rutilus and eight other cyprinid fish by cross-species amplification, and a novel test for detecting hybrids between roach and other cyprinids. Mol Ecol Resour 8:462-465.
Hauge XY and Litt M (1993) A study of the origin of 'shadow bands' seen when typing dinucleotide repeat polymorphism by the PCR. Hum Mol Genet 2:411-415.

Holmen J, Vollestad LA, Jakobsen KS and Primmer CR (2005) Cross-species amplification of zebrafish and central stoneroller microsatellite loci in six other cyprinids. J Fish Biol 66:851-859.

Hotz H, Beerli P and Spolsky C (1992) Mitochondrial DNA reveals formation of nonhybrids frogs by natural matings between hemiclonal hybrids. Mol Biol Evol 9:610-620.

Huang MT, Hsien-Shao Tsao E and Hon-Tsen Yu A (2003) Isolation and cross-species amplification of microsatellite loci in the freshwater minnow Zacco pachycephalus (Teleostei, Cyprinidae) for diversity and conservation genetic analysis. Mol Ecol Notes 3:567-569.

Inacio A, Matos I, Machado M and Coelho MM (2010) An easier method to identify the individual genome composition in allopolyploid complexes. J Fish Biol 76:1995-2001.

Jarne P and Lagoda PJ (1996) Microsatellites, from molecules to populations and back. Trends Ecol Evol 11:424-429.

Jones CJ, Edwards K, Castiglione S, Winfield MO, Sala F, Van de Wiel C, Bredemeijer G, Vosman B, Matthes M, Daly A, et al. (1997) Reproducibility testing of RAPD, AFLP and SSR markers in plants by a network of European laboratories. Mol Breed 3:381-390.

Lampert KP, Lamatsch DK, Schories S, Hopf A, Garcia de León FJ and Schartl M (2006) Microsatellites for the gynogenetic Amazon molly, Poecilia formosa: Useful tools for detection of mutation rate, ploidy determination and overall genetic diversity. J Genet 85:67-71.

Mesquita N, Cunha C, Hänfling B, Carvalho GR, Ze-Ze L, Tenreiro R and Coelo MM (2003) Isolation and characterization of polymorphic microsatellite loci in the endemic Portuguese freshwater fish Squalius aradensis (Cyprinidae). Mol Ecol Notes 3:572-574.

Neff BD and Gross MR (2001) Microsatellite evolution in vertebrates: Inference from AC dinucleotide repeats. Evolution 55:1717-1733.

O'Reilly PT, Hamilton LC, McConnell SK and Wright JM (1996) Rapid analysis of genetic variation in Atlantic salmon (Salmo salar) by PCR multiplexing of dinucleotide and tetranucleotide microsatellites. Can J Fish Aquat Sci 53:2292-2298.

Pala I and Coelho MM (2005) Contrasting views over a hybrid complex: Between speciation and evolutionary "dead end". Gene 347:283-294.

Pala I, Schartl M, Sólveig T and Coelho MM (2009) Sex determination in the Squalius alburnoides complex: An initial characterization of sex cascade elements in the context of a hybrid polyploidy genome. PLoS One 4:e6401.

Ramsden C, Bériault K and Bogart JP (2006) A nonlethal method of identification of Ambystoma laterale, A. jeffersonianum and sympatric unisexuals. Mol Ecol Notes 6:261-264.

Robalo JI, Sousa Santos C, Levy A and Almada VC (2006) Molecular insights on the taxonomic position of the paternal ancestor of the Squalius alburnoides hybridogenetic complex. Mol Phylogenet Evol 39:276-281.

Salgueiro P, Carvalho GR, Collares-Pereira MJ and Coelho MM (2003) Microsatellite analysis of genetic population structure of the endangered cyprinid Anaecypris hispanica in 
Portugal: Implications for conservation. Biol Conserv 109:47-56.

Sambrook J, Fritsch EF and Maniatis T (1989) Molecular Cloning: A Laboratory Manual. 2nd edition. Cold Spring Harbor Laboratory Press, Cold Spring Harbor.

Sousa-Santos C, Robalo J, Collares-Pereira MJ and Almada V (2005) Heterozygous indels as useful tools in the reconstruction of DNA sequences and in the assessment of ploidy level and genomic constitution of hybrid organisms. DNA Sequence 16:462-467.

Turner TF, Dowling TE, Broughton RE and Gold JR (2004) Variable microsatellite markers amplify across divergent lin- eages of cyprinid fishes (subfamily Leuciscinae). Conserv Genet 5:279-281.

Weber JL (1990) Human DNA polymorphisms based on length variations in simple sequence tandem repeats. In: Davies KE and Tilghman SM (eds) Genome Analysis, v. 1. Genetic and Physical Mapping. Cold Spring Harbor Laboratory Press, Cold Spring Harbor, pp 159-181.

Associate Editor: Louis Bernard Klaczko

License information: This is an open-access article distributed under the terms of the Creative Commons Attribution License, which permits unrestricted use, distribution, and reproduction in any medium, provided the original work is properly cited. 